УДК: 336.76

Оригинални научни рад
ПОСЛОВНА ЕКОНОМИЈА

BUSINESS ECONOMICS

Година IX

Број I

стр. $141-158$

др Никола Радивојевић', проф. с.р.

Висока техничка школа струковних студија, Крагујевац

Славица Петровић Радивојевић²

Економска школа, Крагујевац

\title{
Александар Ивановић
}

Школска управа, Крагујевац

\section{АНАЛИЗА ПЕРФОРМАНСИ МОДИФИКОВАНИХ RISKMETRICS МОДЕЛА НА ТРЖИШТИМА У НАСТАЈАЊУ: СТУДИЈА СЛУЧАЈА ФИНАНСИЈСКИХ ТРЖИШТА ЗЕМАЉА БИВШЕ ЈУГОСЛАВИЈЕ}

\begin{abstract}
САЖЕТАК: У раду аутори анализирају перформансе модификованих RiskMetrics модела на тржиштима у настајању. Модификације стандардног RiskMetrics модела извршене су како би се RiskMetrics методологија прилагодила карактеристикама тржишта у настајању. Оне подразумевају инкорпорирање нормалног $G A R C H$ модела, $G A R C H$ модела који се базира на претпоставци да иновације следе Студентову m дистрибуцију и нелинеарног $G A R C H$ модела у стандардну RiskMetrics методологију. Тестирање је извршено на финансијским тржиштима у настајању земаља бивше Југославије, са циљем да се добије одговор на питање да ли је важнија спецификација модела волатилности или претпоставка о дистрибуцији иновација за унапређење апликативности RiskMetrics модела на тржиштима у
\end{abstract}

\footnotetext{
1 radivojevic034@gmail.com

2 caca034@yahoo.com
} 
настајању.

Кльчне речи: Вредност при ризику, RiskMetrics, GARCH модел, волатилност, тржишта у настајању

\section{УвоД}

Као реакција на низ великих финансијских потреса, који су се одиграли током деведесетих година XX века, а посебно немогућност њиховог предвиђања и величина губитака који су произвели, у савременим финансијама развијени су бројни концепти за управљање и мерење тржишних ризика. Међу њима најпознатији и најчешће примењиван концепт јесте вредност при ризику (Value at Risk - VaR). Концепт представља методолошки оквир за мерење и процену тржишних ризика којима су изложени учесници на финансијским тржиштима. Нуди интегрисани начин управљања тржишним ризицима комбиновањем свих фактора ризика, уважавајући степене њихове корелисаности, у један показатељ који представља једноставну и конзистентну меру ризика за различите позиције и различите врсте ризика. На тај начин омогућава лако разумевање изложености ризику и компарацију различитих финансијских инструмената, који до примене концепта нису били упоредиви.

Експанзија концепта започела је 1996. године, када је Базелски комитет прописао $V a R$ као званичну меру тржишног ризика. Истовремено J.П. Морган банка обелоданила је и учинила доступном јавности своју методологију, под називом RiskMetrics, за мерење и управљање тржишним ризицима. Данас RiskMetrics модел, у литератури познат под називом делта експоненцијално пондерисан нормалан модел $V a R$, представља најпознатију приступ за процену тржишних ризика у банкама. Разлог широке распрострањености модела јесте како у једноставности примене тако и у његовој поузданости. Модел се засниван на претпоставци да се волатилности појављују у кластерима и да сутрашња варијанса зависи од прошлих реализација. То овај модел $\mathrm{VaR}$ чини веома погодним у условима променљиве волатилности, што је једна од основних карактеристика тржишта у настајању. Међутим, претпоставка норамлности приноса је у супротности са појавом дебелих репова. Ова некомпатибилност доводи до тога да RiskMetrics потцењује стварни ниво тржишног ризика на тржиштима у настајању, о чему сведоче бројна емпиријска истраживања. Поред овога, RiskMetrics не уважава појаву асиметрије у финансијским подацима. 
Емпиријска истраживања Радивојевића и Станчића (2014) показују да инкорпорирање нормалног $G A R C H(\mathrm{p}, \mathrm{q})$ модела у RiskMetrics методологију доприноси у извесној мери унапређењу апликатинвности RiskMetrics модела на тржиштима у настајању. Међутим, поједини аутори попут Росигнола и сарадника $(2012,2013)$ истичу да је важнија претпоставка дистрибуције приноса него спецификација модела волатилности. С обзиром на то да су за тржишта у настајању, поред хетероскедастичности и дебели репови уобичајена појава, отуда је за ова тржишта погодинија претпоставка о дистрибуцији која кооптира дебеле репове него претпоставка нормалности. У том контексту примена Cmyденm m GARCH(p,q) модела би требало значајније да допринесе унаређењу RiskMetrics методологије на тржиштима у настајању, у контексту задовољења правила валиднсоти модела VaR Базелског комитета.

Отуда, циљ овог рада је да испита да ли икорпорирање $G A R C H(p, q)$ модела који се заснива на претпоставци да иновације следе Cmyденm m дистрибуцију доводи до значајнијег унапређења перформанси RiskMetrics модела на тржиштима у настајању у односу на инкорпорирање нормалног GARCH(p,q) модела у RiskMetrics модел. Такође, у раду ће бити извршено и тестирање апликативности модификованог RiskMetrics модела који се базира на нелинеарном GARCH моделу (NGARCH), како би се одговорило на питање да ли је важнија спецификација модела волатилности или претпоставка дистрибуције иновација за апликативност RiskMetrics модела на тржиштима у настајању, имајући у виду истраживања Росигнола и сарадници (2012, 2013), с једне, али и истраживања Сенера и сарадника (2012) и Луиза и сарадника (2014) са друге стране, која сведоче у прилог примени модела волатилности који уважавају асиметрију.

\section{TЕОРИJCKЕ ОСНОВЕ RISKMETRICS МОДЕЛА}

RiskMetrics модел представља параметарски модел који је заснован на J.П. Моргановом приступу за квантификовање изложености портфолија тржишном ризику. У суштини Ј.П.Морганов приступ представља скуп методологија за статистичко мерење тржишног ризика. Ове методологије се заснивају на процени матрице варијанса-коваријанса приноса портфолија и обухватају процену три матрице: матрицу варијанса-коваријанса дневних приноса (релевантну за процену VaR која кореспондира са дневним приносима портфолија); матрицу варијанса-коваријанса засновану на месечним приносима (релевантну за процену $V a R$ која кореспондира са ме- 
сечним приносима портфолија) и тзв. "регулаторну" матрицу варијансаковаријанса, која је у складу са захтевима Базелског комитета.

Основна разлика између RiskMetrics модела и осталих параметарских модела заснованих на матрици варијанса-коваријанса јесте у томе што се RiskMetrics заснива на условној дистрибуцији приноса. Процес генерисања приноса се описује применом “временски условног” модела случајног хода. Уз опште прихваћену претпоставку да је средња вредност приноса једнака нули $(\mu=0)$, процес генерисања приноса се представља на следећи начин: ${ }^{3}$

$$
\begin{aligned}
& r_{i, t}=\sigma_{i t} \varepsilon_{i t} \\
& \varepsilon_{i t} \sim N(0,1) \quad \varepsilon_{t} \sim \operatorname{MVN}\left(0, R_{t}\right) \quad \varepsilon_{t}=\left[\varepsilon_{1 t}, \varepsilon_{2 t}, . . \varepsilon_{N t}\right]
\end{aligned}
$$

при чему су:

$\varepsilon$ - идентично и независно дистрибуирна иновација (случајна променљива) и-те хартије од вредности у тренутку (t), са средином нула и варијансом 1

$\varepsilon$ - вишедимензионална нормално дистрибуирана иновација (случајна променљива). са вектором нила средина и матьицом корелације $\mathrm{N} x \mathrm{~N}$ независних иновачија (случајних променльивих)

уз напомену да се промене у вредности портфолија изражавају у форми логаритамских приноса. Тачније, сва израчунавања у RiskMetrics-у се заснивају на употреби логаритамских приноса.

Приноси портфолија генерисани применом ове варијанте модела случајног хода задовољавају хипотезу о условној нормалној дистрибуцији. Стандардна девијација исказана у овој варијанти модела случајног хода јесте временски условљена јер зависи од претходних реализација. Отуда се њена процена врши применом приступа EWMA. Управо примена овог приступа представља кључну разлику у односу на моделе $V a R$ код којих се оцена волатилности врши применом приступа једнако пондерисаних покретних средина.

Иако ове модификације, на први поглед, не изгледају значајно, њихово инкорпорирање у модел има значајних импликација на процену $\mathrm{VaR}$. Пре свега, уз стандардну претпоставку за све делта моделе (претпоставку линеарности), примена логаритамских приноса је еквивалентна претпоставци

3 J.P. Morgan, (1996), "RiskMetrics“, Technical Documen, 4th edition, New York, p. 73. 
да је вредност, односно принос портфолија, логнормално дистрибуиран. Стога се може рећи да се RiskMetrics модел заснива на претпоставци о условној логнормалној дистрибуцији приноса. За поједине факторе ризика, као што су цене акција, претпоставка логнормалне дистрибуције вредности портфолија је погоднија за описивање дистрибуције дневних приноса него претпоставка нормалне дистрибуције. ${ }^{4}$ Друго, примена приступа $E W M A$ за оцену волатилности, омогућава да се кооптира ефекат временске променљивости волатилности. Употреба приступа једнако пондерисаних покретних средина јесте оптимална када је волатилност константна. Међутим, ова претпоставка није реална будући да бројна емпиријска истраживања показују да волатилности нису константне, већ се групишу у периоде високе и ниске варијабилности. Пошто између волатилности постоји значајна позитивна аутокорелација, када се врши процена очекиване волатилности применом историјских података, потребно је сагледати како је текућа волатилност позитивно корелисана са волатилношћу из претходног периода. Другим речима, потребна је оцена условне волатилности. Када је опсервиран велики принос, процена волатилности треба да буде повећана јер после великог приноса треба очекивати велики принос без обзира на смер, и обратно у случају малих приноса. Управо се ово постиже приписивањем већих пондера скоријим опсервацијама. ${ }^{5}$ у ситуацији повећане волатилности на тржишту, примена приступа једнако пондерисаних покретних средина, као стандардне технике за оцену безусловне волатилности, резултираће повећањем процене волатилности. То ће представљати тачан одраз понашања кластера волатилности на тржишту. Међутим, проблем ће се јавити након смиривања тржишта због присуства тзв. ефекта духа. Због система фиксних пондера, овај приступ не води рачуна да ли су се екстремни губици десили у далекој или недавној прошлости, тако да ће екстремни губитак који се десио далеко у прошлости током целог периода посматрања утицати са истим интензитетом на оцену волатилности. У случају смиривања тржишта, ово ће утицати да процена VaR буде прецењена у односу на стварни ризик. Са друге стране, приступ EWMA примењује систем експоненцијално опадајућих пондера, са

4 Ammann, M., Reich, C., (2001), "VaR for nonlinear Financial Instruments - Linear Approximation or full Monte Carlo?", Working Paper, p. 4.

5 Pearson, N., (2002). Risk budgeting: Portfolio Problem Solving with Value at Risk, John Wiley and Sons, Chichester, p. 47. 
константним фактором опадања $(\lambda)$. Овај фактор одражава утицај прошлих опсервација на оцену текуће волатилности. Опсервацијама различите старости приписују се различити пондери, који експоненцијално опадају за опсервације које потичу из даље прошлости. На тај начин се наглашава значај и утицај скоријих опсервација у односу на оне из даље прошлости на оцену волатилности. Ефекат оваквог начина пондерисања јесте да ће утицај екстремних губитака на оцену волатилности опадати како они постају старији, чиме се елиминише проблем ефекта духа.

Оцена волатилности у приступу EWMA врши се применом следећег обрасца: ${ }^{6}$

$$
\sigma_{t}=\sqrt{\frac{1-\lambda}{1-\lambda^{N}} \sum_{n=1}^{N} \lambda^{n-1}} r_{i t-n}^{2}
$$

са коваријансом

$$
\sigma_{i j}=\frac{1-\lambda}{1-\lambda^{N}} \sum_{n=1}^{N} \lambda^{n-1} r_{i t-n} r_{j i-n}
$$

при чему сv:

$\sigma_{t} \quad$ - стандардна девијација портфолија

$\sigma_{i i} \quad$ - коваријанса и-те и ј-те стопе приноса

$r_{i i} \quad$ - стопа приноса и-тог /j-тог фактора ризика портфолија

$N \quad$ - укупан броі опсервација

$\lambda \quad$ - фактор опадана

Фактор опадања може узимати вредности у интервалу . У случају да је $(\lambda)$ једнака јединици оцена волатилности применом EWMA је еквивалентна оцени волатилности која се добија применом приступа једнако пондерисаних покретних средина. То значи да приступ једнако пондерисаних покретних средина представља специјалан случај EWMA. Коефицијент $(1-\lambda) /\left(1-\lambda^{\mathrm{H}}\right)$ се појављује у изразу јер је сума $\sum_{n=1}^{N} \lambda^{n-1}=\left(1-\lambda^{N}\right) /(1-\lambda)$

6 Исто, стр. 47. 
или приближно 1/(1- $\lambda)$, када N . Атрактивност приступа EWMA јесте да под одређеним претпоставкама, може бити написан у рекурзивном облику, који је нарочито погодан за оцену волатилности у квантитативним финансијама. Под претпоставком да је $\mu=0$ и да се предвиђа варијанса за период $(\mathrm{t}+1)$, на основу информација расположивих у тренутку $(\mathrm{t})$ рекурзивни облик се добија на основу следећег израза: ${ }^{7}$

$$
\begin{aligned}
& \sigma_{1 t+1 / t}^{2}=(1-\lambda) \sum_{i=0}^{\infty} \lambda^{i} r_{1 t-i}^{2}= \\
& =(1-\lambda)\left(r_{1 t}^{2}+\lambda r_{1 t-1}^{2}+\lambda^{2} r_{1 t-2}^{2}+\ldots\right)= \\
& =(1-\lambda) r_{1 i}^{2}+\lambda(1-\lambda)\left(r_{1 t-1}^{2}+\lambda r_{1 t-2}^{2}+r_{1 t-3}^{2}=\right. \\
& =\lambda \sigma_{1 t \mid t-1}^{2}+(1+\lambda) r_{1 i}^{2}
\end{aligned}
$$

Кореновањем израза (4) се добија израз за оцену RiskMetrics волатилности: ${ }^{8}$

$$
\sigma_{1 t \mid t+1}=\sqrt{\lambda \sigma_{1 \mid t-1}^{2}+(1+\lambda) r_{, t}^{2}}
$$

Кључно питање код приступа EWMA јесте број опсервација $(\mathrm{N})$ и избор фактора опадања. Када је волатилност константа, оптимална је примена приступа једнако пондерисаних покретних средина са што већим бројем опсервација, по могућству да буде једнак броју доступних опсервација. ${ }^{9}$ У случају временски променљиве волатилности само су скорије опсервације релевантне. Тако је потребно узети само најновије податке или користити приступ EWMA са релативно малим фактором опадања. Нижи фактор опадања значи брже опадање утицаја каснијих опсервација, па је стога препоручљив у условима велике волатилности. Другим речима, то значи да је оцена волатилности базирана на неколико најновијих

7 J.P. Morgan, (1996), op., cit., str. 81-82.

8 Исто, стр. 82.

Нотација у субскрипту

наглашава чињеницу да се ради о временски условној волатилности, што је складу са постојањем позитивне аутокорелације између волатилности.

9 Pearson, N., (2002), оп., цит., стр. 47. 
опсервација, мада нису занемарене ни информације садржане у ранијим опсервацијама. ${ }^{10}$

Међутим, иако је велики број аутора проучавао теоријске аспекте схеме пондерисања у RiskMetrics моделу (Фалон (1996), Хендрикс (1996), Алехандер и Леиг (1997)) још увек не постоји прецизан алгоритам за утврђивање оптималног фактора опадања. Ј.П.Морган сугерише употребу униформног система пондерисања са $(\lambda)$ од 0,94 за оцену дневне, односно са $(\lambda)$ од 0,97 за оцену месечне волатилности. Иако Александер (2008) критикује употребу $(\lambda)$ од 0,94 за оцену дневне волатилности као сувише висок фактор опадања за велики број тржишта, истраживања Хендрикс-а (1996) показала су да представља добар избор у условима високе варијабилности волатилности. Са $(\lambda)$ од 0,94 пондери рапидно опадају, те се на тај начин наглашава значај и утицај скоријих опсервација у односу на оне из даље прошлости. Опсервација стара само 30 дана добија пондер који је мањи од 0,01, док опсервација стара 66 дана добија пондер мањи од 0,001. ${ }^{11}$

На основу претходно реченог могу се извести следеће три кључне предности RiskMetrics модела. Прво, RiskMetrics представља унапређење у односу на моделе $V a R$ засноване на приступу једнако пондерисаних покретних средина јер уважава појаву хетероскедастичности у серијама приноса портфолија. Из тог разлога, Моса и Болен (2000) подржавају употребу RiskMetrics модела. У својим истраживањима тестирали су непристрасност у оцени дневних $\mathrm{BaP}$ и открили да су процене $\mathrm{VaR}$ изузетно осетљиве на избор узорка и избор приступа за оцену дневне волатилности. Резултати истраживања Ј.П.Морган банке и Фалона, сведоче у прилог RiskMetrics-a у односу на моделе који се заснивају на примени приступа једнако пондерисаних покретних средина. Ова истраживања показују да примена RiskMetrics-а доводи до минимизирања грешке у предвиђању волатилности. Ј.П.Морган банка никада није објавила колико је то смање, док резултати Фаллон-а указују на то да је оно минимално. Хипотетички посматрано, ако би биле на располагању бесконачне временске серије података то смањење би, сагласно резултатима представљеним у Ј.П.МорганРојтерсовом Техничком документу, могло да буде и до 50\%.

Друго, једини непознати параметар у моделу јесте фактор опадања. Проналажење оптималног фактора опада у пракси се своди на утврђивање

10 Jackson, P., Maude, D., Perraudin, W., (1998), "Bank Capital and Value at Risk“, Bank of England Working Paper, No. 79. p. 18.

11 О утицају величине фактора опадања детаљније видети у Pearson, N., (2002), оп., цит., стр. 47. 
$(\lambda)$, која доводи до минимизирања грешке у предвиђању волатилности, сагласно процедури коју је предложила Ј.П.Морган банка. Оптималан фактор опадања утврђује се на следећи начин: ${ }^{12}$

$$
\sim=\sum_{i=1}^{N} \phi_{i} \tilde{\lambda}_{i} \text { ca } \phi_{i}=\theta_{i}^{-1} / \sum_{i=1}^{N} \theta_{i}^{-1}
$$

уз услов да је сума пондера једнака 1 и $\theta_{i}=\tau_{i} /\left(\sum_{i=1}^{N} \tau_{i}\right)$, односно

$$
\Pi=\sum_{i=1}^{N} \tau_{i}
$$

при чему су:

$\tilde{\lambda}$ - оптималан фактор опадања

- и-ти оптималан фактор опадања

$\phi_{i}^{i} \quad$ - учешће и-тог оптималног фактора опадања

$N$ - број временских серија у бази података

$\vartheta_{i} \quad$ - релативна гпешгка

- и-ти RMES (корен средњег квадратног одступања) који кореспондира са и-ти

$\tau_{i}$ оптималним фактором опадања

П - сума свих $\mathrm{N}$ минималних грешака $\tau_{\mathrm{i}}$

Оптималан фактор опадања који је предложила Ј.П. Морган банка у ствари представља пондерисани просек оптималних фактора опадања за све временске серије података из њихове базе. Постоји могућност употребе различитих фактора опадања ${ }^{13}$, где се за сваку активу из портфолија банке утврђује оптималан фактор опадања. Међутим, проучавајући факторе опадања за велики број различитих актива, Ј.П.Морган банка је открила да су оцене веома сличне. Из тог разлога препоручује употребу једног фактора опадања за оцену волатилности портфолија.

Tреће, за оцену дневне волатилности потребно је релативно мало података. Са фактором опадања од 0,94 , за оцену дневне волатилности портфолија потребно је свега 100 опсервација. После свега 100 опсервација, кумулатив пондера износи , тако да је 99,8\% пондера укључено у процену $\mathrm{VaR}$. Због тога је довољно имати на располагању само 100 података о дневним стопама приноса портфолија.

12 J.P. Morgan, (1996), оп., цит., стр. 99.

13 Ovakav sistem ponderisanja primenjuje se u CSFB's PrimeRisk-u. 
Међутим, RiskMetrics има низ ограничења. Пре свега, и овде је присутан проблем кооптирања дебелих репова. Претпоставка нормалности је у супротности са чињеницом да се екстрмни приноси дешавају чешће него претпоставка о нормалној дистрибуцији предвиђа. Џексон и сарадници (1997) су показали да схема поднерисања са рапидно опадајућим пондерима повећава пристрасност у вероватноћама репа. Друго, RiskMetrics игнорише да волатилности на финансијским тржиштима теже да буду стабилне у дугом року. Отуда је погодан само за оцену дневне волатилности. У том случају, оцена волатилности је слична оценама волатилности добијеним применом $G A R C H(\mathrm{p}, \mathrm{q})$ модела. Ако се $G A R C H(\mathrm{p}, \mathrm{q})$ модел искаже (у најједноставнијем облику) у облику који текућу волатилност повезује са волатилношћу из претходног раздобља $(G A R C H(1,1))$, лако се може уочити да EWMA представља специфичан случај $G A R C H(\mathrm{p}, \mathrm{q})$ модела: ${ }^{14}$

$$
\begin{aligned}
& \sigma_{t+1}^{2}=\omega+\alpha r_{t}^{2}+\beta \sigma_{t}^{2} \\
& \alpha+\beta \leq 1
\end{aligned}
$$

Када су $\omega=0, \beta=\lambda$ и $\alpha=1-\lambda$, израз за оцену волатилности применом приступа EWMA је еквивалентан изразу за оцену волатилности применом $\operatorname{GARCH}(\mathrm{p}, \mathrm{q})$ модела са дугом меморијом. ${ }^{15}$ Међутим, у дугом року, RiskMetrics може да произведе само хипотетичке оцене волатилности. То се најбоље може сагледати ако се безусловна варијанса $\left(\sigma^{2}\right)$ искаже на следећи начин, преко параметара модела:

$$
\sigma^{2}=\omega /(1-\alpha-\beta)
$$

Из израза (8) се јасно види да модели, код којих су $\alpha+\beta=1$, што је случај код RiskMetrics-a, не могу на адекватан начин да дефинишу дугорочну варијансу јер игноришу да волатилности теже да буду стабилне у дугом року. Са друге стране, GARCH имплицитно претпоставља да је дугорочна варијанса стабилна током времена. То се може видети ако се израз за дугорочну варијансу (8) искаже преко ( $\omega)$ и тај израз се замени у изразу (7):

$$
\sigma_{t+1}^{2}=(1-\alpha-\sigma) \sigma^{2}+\alpha r_{t}^{2}+\beta \sigma_{t}^{2}=\sigma^{2}+\alpha\left(r_{t}^{2}-\sigma^{2}\right)+\beta\left(\sigma_{t}^{2}-\sigma^{2}\right)
$$

14 Christoffersen, P., (2003). Elements of Financial Risk Management, Academic Press, London, p. 23.

15 Engle, R., Merzrich, J., (1995), “Grappling with GARCH”, Risk, Vol. 8, No. 9, pp. 112-11\%. 
Израз (9) показују да је сутрашња волатилност пондерисани просек дугорочног кретања варијансе (волатилности), квадрата данашњег приноса и данашње варијансе, односно, сутрашња варијанса је израз дугорочног кретања варијансе, којој треба нешто додати (или одузети) ако је данашњи принос на квадрат изнад (испод) његовог дугорочног просека и нешто додати (одузети) ако је данашња варијанса изнад (испод) њеног дугорочног просека. Другим речима, разлика између GARCH(p,q) модела и RiskMetricsа јесте у томе што hе RiskMetrics у случају да је текућа волатилност висока, предвиђати да ће она бити висока и у будућности, док GARCH води рачуна да ће волатилност у будућности тежити да се врати на просечан ниво дугорочне варијансе.

\section{ПОДАЦИ И МЕТОДОЛОГИЈА ИСТРАЖИВАњА}

За тестирање валидности модела су коришћени дневни логаритамски приноси општих берзанских индекса тржишта у настајању бивших земаља Југославије. Тестирани индекси су BIRS, MONEX20, MBI10, BELEXline и $C R O B E X$. Подаци су прикупљени са Блумберговог веб сајта за период од 02.02.2009. до 02.02.2012. године. Прикупљени подаци покривају период временски променљиве волатилности на тржишту ЕУ. Логаритамски приноси су генерисани на следећи начин:

$$
{ }_{i, t}=\ln \left(\frac{P_{i, t}}{P_{i, t-1}}\right)
$$

при чему сv:

$r_{\text {i.t. }}$ - логаритамски принос за дан $(m)$

$P_{i, t} \quad$ - вредност посматраног индекса на затварану за текући дан

$P_{i, t-1}$ - вредност посматраног индекса на затварану претходног дана

Дневне процене VaR су начињене за период од 02.02.2011. до 02.02.2012. године. Као репрезент RiskMetrics модела који се базира на нормалном GARCH моделу, коришћен је RM500-GARCH $(1,1)$ модел, будћи да емпиријска истраживања показују да је довољно узети лег од једног дана, уз напомену да је спефицикација $G A R C H(1,1)$ модела приказана изразом (7). Као репрезент RiskMetrics модела који се базира на претпоставци да иновације следе Cmyдентову $m$ дистрибуцију коришћен је модел $R M 500$ $G A R C H(1,1)-m(d)$, док је RM500-NGARCH(1,1) модел развијен као репрезент модификованог RiskMetrics модела који је способан да кооптира асиме- 
трију. $N G A R C H(1,1)$ предстваља модификован нормалан $G A R C H$ модел. Прецизније, нормалан GARCH модел је модификован тако да пондери који се додељују приносима зависе од тога да ли је принос позитиван или негативан. Спецификација NGARCH(1,1) модела је приказана изразом (11):

$$
\sigma_{t+1}^{2}=\omega+\alpha\left(r_{t}-\theta \sigma_{t}\right)^{2}+\beta \sigma_{t}^{2}=\omega+\alpha \sigma_{t}^{2}(z-\theta)^{2}+\beta \sigma_{\dot{o}}^{2}
$$

уз напомену да позитиван део вести, $\mathrm{z}_{\mathrm{t}}>0$, има мањи утицај на варијансу него негативан, ако је $\theta>0$.

Да би се обезбедио исти узорак за тестирање валидности модела за свако тржиште овај период је узет као период за тестирање валидности модела. Остатак опсервација, период од 02.02.2009. до 01.02.2011. године, употребљен је за добијање иницијалних процена $\mathrm{VaR}$, оцену параметара и калибрирање модела волатилности.

За разлику од стандардног RiskMetrics модела, GARCH модели волатилности захтевају оцену непознатих параметара модела. Оцена параметара модела волатилности добијене су применом метода максималне и квазимаксималне веродостојности. Прва је коришћена за оцену параметара модела волатилности који се заснивају на претпоставци нормалности, а друга за оцену параметара $G A R C H(1,1)-m(\partial)$ модела. Оцене параметара дате су у табели 1.

Табела 1 - Оиене параметара модела волатилности

\begin{tabular}{|c|c|c|c|c|c|}
\hline & BIRS & MONEX20 & $M B 110$ & BELEXline & CROBEX \\
\hline \multicolumn{6}{|c|}{ Параметри модела $G A R C H(1,1)$} \\
\hline$\alpha$ & 0,182 & 0,444 & 0,324 & 0,397 & 0,146 \\
\hline$\beta$ & 0,817 & 0,492 & 0,675 & 0,602 & 0,850 \\
\hline$\omega$ & 0,000 & 0,000 & 0,000 & 0,000 & 0,000 \\
\hline \multicolumn{6}{|c|}{ Параметри модела $G A R C H(1,1)-t(d)$} \\
\hline$\alpha$ & 0,438 & 0,301 & 0,234 & 0,298 & 0,052 \\
\hline$\beta$ & 0,175 & 0,166 & 0,206 & 0,689 & 0,051 \\
\hline$\omega$ & 0,000 & 0,000 & 0,000 & 0,000 & 0,000 \\
\hline$v$ & 5,273 & 4,000 & 4,000 & 6,638 & 4,000 \\
\hline \multicolumn{6}{|c|}{ Параметри модела $\mathrm{N} G A R C H(1,1)$} \\
\hline$\alpha$ & 0,057 & 0,051 & 0,332 & 0,447 & 0,209 \\
\hline
\end{tabular}




\begin{tabular}{|r|c|c|c|c|c|}
\hline $\boldsymbol{\beta}$ & 0,675 & 0,735 & 0,665 & 0,549 & 0,770 \\
\hline $\boldsymbol{\omega}$ & 0,000 & 0,000 & 0,000 & 0,000 & 0,000 \\
\hline $\boldsymbol{\theta}$ & 2,175 & 2,055 & 0,101 & 0,069 & 0,316 \\
\hline
\end{tabular}

Извор - Аутори

\section{РЕЗУЛТАТИ ТЕСТИРАЊА ВАЛИДНОСТИ МОДЕЛА}

У овом делу рада представљени су и анализирани резултати тестирања валидности модела. Модели су процењени у погледу тачности њихових процена $V a R$ током последњих 253 дана периода посматрања. Овај период је означен као период тестирања валидности модела. Сваки модел је тестиран на следећи начин: дневне процене $V a R$, које су добијене за нивое поверења од 99\%, поређене су са стварним кретањима приноса у периоду од 02.02.2011 до 02.02.2012. године. У случају када је стварни губитак био већи од процене $V a R$ начињене за тај дан, евидентирано је да се десило прекорачење. Затим је утврђен укупан број/проценат прекорачења током периода тестирања валидности.

Према Џориону (2001) модел јесте валидан уколико је број прекорачења једнак (1-ниво поверења). У овом случају, то значи да укупан број прекорачења, тj. дана када је стварни губитак био већи од процене VaR начињене за тај дан, не сме да буде већи од 3. Другим речима, проценат прекорачења $\mathrm{VaR}$ не сме да пређе $1 \%$ од укупног броја процена $\mathrm{VaR}$.

Број, односно проценат прекорачења $V a R$ током периода тестирања валидности модела од 02.02.2011 до 02.02.2012. године, посебно за сваки модел и за свако тржиште, су приказани у табели 2.

Табела 2 - Број/проценат прекорачена

\begin{tabular}{|l|c|c|c|c|c|c|}
\hline & \multicolumn{2}{|c|}{ RM500-GARCH(1,1) } & \multicolumn{2}{c|}{ RM500-GARCH-t(d)(1,1) } & \multicolumn{2}{c|}{ RM500- NGARCH(1,1) } \\
\hline Индекси & Бр. прекорачења & $\%$ & Бр. прекорачења & $\%$ & Бр. прекорачења & $\%$ \\
\hline BIRS & 6 & 2,37 & 5 & 1,98 & 4 & 1,58 \\
\hline MONEX20 & 3 & 1,18 & 5 & 1,98 & 3 & 1,18 \\
\hline MBI10 & 3 & 1,18 & 2 & 0,79 & 1 & 0,39 \\
\hline BELEXline & 2 & 0,79 & 4 & 1,58 & 2 & 0,79 \\
\hline CROBEX & 4 & 1,58 & 3 & 1,18 & 3 & 1,18 \\
\hline
\end{tabular}

Извор - Аутори 
На основу резултата приказаних у табели 2 може се закључити да је проценат прекорачења код сваког модела у већини случајева већи од теоријске вредности. Мањи проценат прекорачења од очекиваног модели су остварили у случају тржишног индекса BELEXline и то модели RM500$\operatorname{GARCH}(1,1)$ и $R M 500-N G A R C H(1,1)$, и у случају тржишног индекса MBI10 и то модели RM500-NGARCH(1,1) RM500-GARCH)-m(d)(1,1). Дакле, према Џорионовом критеријму може се закључити да је најбоље перформансе остварио RM500-NGARCH $(1,1)$ модел. Имајући у виду само овај критеријум, може се закључити да инкорпорирање $G A R C H(\mathrm{p}, \mathrm{q})$ модела који се заснива на претпоставци да иновације следе Студентову $m$ дистрибуцију у RiskMetrics методологију доприноси унапређењу апликатинвности RiskMetrics модела на тржиштима у настајању у односу на примену нормалног GARCH модела, будући да је модел $R M 500-G A R C H-m(\partial)(1,1)$ генерисао мањи број прекорачења у односу на $R M 500$ - $G A R C H(1,1)$ модел у случају три индекса. Такође, само на онснову Џорионовог критеријума може се закључити да је спецификација модела волатиности важнија од претпоставке дистрибуције иновације јер је модел $R M 500-\operatorname{NGARCH}(1,1)$ имао најбоље перформансе на тестираним тржиштима.

Међутим, да би се формално испитало да ли се тестирани модели могу сматрати валидним, неопходно је тестирати хипотезу да је проценат прекорачења једнак теоријској вредности, наспрам алтернативне хипотезе која гласи да се проценат прекорачења разликује од теоријске вредности. За ту сврху у раду коришћен је Купиецов тест безусловног покрића. Купиецов тест безусловног покрића представља најчешће коришћен модел за тестирање валидности модела $\mathrm{VaR}$. Валидност модела је тестирана за ниво значајности теста од 95\%. Овај ниво значајности теста генерише јасне доказе о користи модела и имплицира да се модел одбаци само ако за то постоје снажни докази. Резултати Купиецовог теста безусловног покрића, за ниво поверења од 95\%, дати су у табели 3.

Табела 3. Резултати Купиецовог теста безусловног

\begin{tabular}{|l|c|c|c|c|c|c|}
\hline & \multicolumn{2}{|c|}{ RM500-GARCH(1,1) } & \multicolumn{2}{|c|}{ RM500-GARCH)-t(d)(1,1) } & RM500- $N G A R C H(\mathbf{1 , 1})$ \\
\hline Индекси & критична вред. & р-вред. & критична вред. & р-вред. & $\begin{array}{c}\text { критична } \\
\text { вред. }\end{array}$ & р-вред. \\
\hline BIRS & 3,47 & 0,062 & 1,896 & 0,168 & 0,733 & 0,391 \\
\hline MONEX20 & 0,083 & 0,772 & 1,897 & 0,168 & 0,083 & 0,772 \\
\hline MB110 & 0,083 & 0,772 & 0,120 & 0,728 & 0,083 & 0,772 \\
\hline BELEXline & 0,120 & 0,728 & 0,733 & 0,391 & 0,120 & 0,728 \\
\hline CROBEX & 0,733 & 0,391 & 0,083 & 0,772 & 0,083 & 0,772 \\
\hline
\end{tabular}

Извор - Аутори 
Као што се може видети из табеле 3, за ниво поверења од 99\% Купиецев тест безусловног покрића су задовољила сва три модела. Тако да се само на основу овог критеријума не може извести закључак који да ли инкорпорирање $G A R C H(p, q)$ модела који се заснива на претпоставци да иновације следе Cmyдентову m дистрибуцију у RiskMetrics методологију доприноси унапређењу апликатинвности РискМетрицс модела на тржиштима у настајању у односу на примену нормалног $G A R C H$ модела, као и да ли је важнија структура модела валотилности од претпоставке о дистрибуцији иновације.

Одговор на ова питања захтева примену неког критеријума за рангирање модела $V a R$. За ту сврху у раду је коришћен критеријум који су промовисали Балабан и сарадници (2004) (the root mean squared error - RMSE). Коефицијенти RMSE су приказани у табели 4.

Табела 4. - Коебиизјенти RMSE за процене VaR

\begin{tabular}{|l|c|c|c|c|c|}
\hline & BIRS & MONEX20 & MB110 & BELEXline & CROBEX \\
\hline RM500-GARCH(1,1) & 0,0212 & 0,0353 & 0,0269 & 0,0221 & 0,0223 \\
\hline $\begin{array}{l}\text { RM500-GARCH-t(d) } \\
(\mathbf{1}, \mathbf{1})\end{array}$ & 0,0208 & 0,0346 & 0,0335 & 0,0202 & 0,0257 \\
\hline $\begin{array}{l}\text { RM500- } \\
\text { NGARCH(1,1) }\end{array}$ & 0,0291 & 0,0421 & 0,0273 & 0,0230 & 0,0247 \\
\hline
\end{tabular}

Извор - Аутори

Резултата приказани у табели 4 показују да је $R M 500-G A R C H-t(d)(1,1)$ jе најбоље рангиран модел на три од пет тржишта, тржишту капитала Републике Српске, Црне Горе и Србије, док је $R M 500-G A R C H(1,1)$ најбоље рангиран модел на тржишту капитала Македоније и Хрватске. Судећи по томе може се реци да инкорпорирање $G A R C H(p, q)$ модела који се заснива на претпоставци да иновације следе Cmyдентову $m$ дистрибуцију у RiskMetrics методологију доприноси унапређењу апликатинвности RiskMetrics модела на тржиштима у настајању у односу на примену нормалног GARCH модела. Према овом критеријуму наслабије рангиран модел јесте RM500$\operatorname{NGARCH}(1,1)$, упркос чињеници да је према Џорионовом критеријуму има најбоље перформанце. Стога се може реци да је важнија претпоставка о дистрибуцији иновација у односу на спецификацију модела. 


\section{ЗАКЉУЧАК}

Имајући у виду резултате истраживања, може се извући закључак да инкорпорирање $G A R C H(\mathrm{p}, \mathrm{q})$ модела који се заснива на претпоставци да иновације следе Cmyдентову $m$ дистрибуцију у RiskMetrics методологију доприноси унапређењу апликатинвности RiskMetrics модела на тржиштима у настајању у односу на примену нормалног GARCH модела, као и да је важнија претпоставка о дистрибуцији иновација у односу на спецификацију модела. Овакав закључак је изведен на основу критеријума за рангирање модела $\mathrm{VaR}$ који су промовисали Балабан и сарадници (2004). Међутим, приликом прихватања овог закључка треба бити опрезен, пре свега, због ограничења самог Купиецовоц теста, али и чињенице да је коришћен само један критеријум за рангирање модела $V a R$. Купеицов тест, иако је у складу са правилима Базелског комитета о валидности модела, даје само безусловну процену јер узима у обзир сва прекорача током целог периода који се користи за процену валидности модела. У условима временски променљиве волатилност веома је значајна процена условне тачности модела, тј. употреба неког теста условног покрића. У раду није коришћен ни један такав тест, будући да је циљ рада био да се испита валидност модела у контексту задовољења правила валидности Базелског комитета.

\section{SUMMARY \\ THE ANALYSIS OF THE MODIFIED RISKMETRICS MODELS PERFORMANCE ON EMERGING MARKETS: A CASE STUDY OF FINANCIAL MARKETS OF FORMER YUGOSLAV COUNTRIES}

In this paper the authors analyze the performance of modified RiskMetrics models on emerging markets. Some modifications of the standard RiskMetrics model have been made in order to adjust RiskMetrics methodology to the characteristics of the emerging markets. These modifications include the incorporation of the regularGARCH model, GARCH model based on the assumption that innovations follow Student $t$ distribution, and nonlinear GARCH model into the standard RiskMetrics methodology. Tests were performed on emerging financial markets of former Yugoslav countries with the objective of answering the question of what is more important: the specification of volatility model or the assumption about distribution of innovations for improvingRisk Metrics model applicability on the emerging markets.

Keywords: Value at Risk, RiskMetrics, GARCH, volatility, emerging markets 


\section{ЛИТЕРАТУРА:}

1. Alexander, C., Market Risk Analysis: Volume IV, Value at Risk Models, John Wiley and Sons, Chichester, 2008.

2. Alexander, C., Leigh, C. T., , "On the CoVaRiance Matrices use in Value at Risk Models", Journal of Derivatives, Vol. 3, No. 4, 1997, pp. 50-62.

3. Ammann, M., Reich, C. "VaR for nonlinear Financial Instruments - Linear Approximation or full Monte Carlo?”, Working Paper, (2001).

4. Balaban, E Bayar, A., Faff, R., "Forecasting Stock Market Volatility: Further International Evidence", Working paper, 2004.

5. Christoffersen, P., Elements of Financial Risk Management, Academic Press, London, 2003.

6. Engle, R., Merzrich, J., "Grappling with GARCH”, Risk, Vol. 8, No. 9, 1995, pp. 112-117.

7. Fallon, W., "Calculating VaR", Working paper, Wharton school, 1996.

8. Hendricks, D., "Evaluation of value at risk models using historical data", Economic Policy Review, Federal Reserve Bank of New York, April, 1996, pp. 39-69.

9. J.P. Morgan, "RiskMetrics", Technical Document, 4th edition, New York, 1996.

10. Moosa, I. A., Bollen, B.;A Benchmark for Measuring Bias in Estimated Daily Value at Risk", Working Paper, La Trobe University, 2000.

11. Pearson, N., Risk budgeting: Porttolio Problem Solving with Value at Risk, John Wiley and Sons, Chichester, 2002.

12. Radivojevic N., Stancic V., "The applicability of modify RiskMetrics model at emerging markets", International Scientific Conference, Contemporary Issues in Economics, Business and Management, Faculty of Economics, University of Kragujevac, 2014.

13. Rossignolo, A., Fethib, M., Shaban, M., "Value-at-Risk models and Basel capital charges Evidence from Emerging and Frontier stock markets," Journal of Financial Stability, No. 8, 2012, pp. 303-319.

14. Rossignolo, F. Adrian, Meryem Duygun Fethib, Mohamed Shaban "Market crises and Basel capital requirements: Could Basel III have beendifferent? Evidence from Portugal, Ireland, Greece and Spain (PIGS)," Journal of Banking \& Finance, Vol. 37, 2013, pp. 1323-1339. 
